\title{
Influence of Seasonal Environmental Changes on The Biochemical Composition of Sea Cucumber (Holothuria tubulosa Gmelin, 1791) in The Dardanelles Strait
}

\author{
Saniye Turk Culha ${ }^{1}$, Meryem Yeşim Çelik ${ }^{2}$, \\ Fatma R. Karaduman', Hakki Dereli ${ }^{1}$, Mehmet Culha ${ }^{1}$, \\ Hasan B. Ozalp ${ }^{3}$, Sevim Hamzacebi ${ }^{1}$, Mustafa Alparslan ${ }^{1}$ \\ 1 - Izmir Katip Celebi University, Izmir, Turkey \\ 2 - Sinop University, Sinop, Turkey \\ 3 - Canakkale Onsekiz Mart Univesity, Canakkale, Turkey
}

Keywords:

Biochemical

Sea cucumber

Holothuria tubulosa

Dardanelles Strait

Article history:

Received 24.04.2017

Received in revised

form 19.06.2017

Accepted 29.06.2017

Corresponding

author:

Meryem Yeşim Çelik

E-mail:

yesimcelik@

yahoo.com.tr

DOI: $10.24263 / 2304-$

974X-2017-6-2-10

\section{Abstract}

Introduction. There is a serious worldwide protein deficiency problem, so it is the obligation to know about edible species and their biochemical composition. Sea cucumbers have great value because of its high protein content. The study comprises monthly data on biochemical content of $H$. tubulosa.

Materials and methods. Monthly variations in biochemical composition of sea cucumbers and environmental interrelationship were investigated from April 2013 to March 2014, from three stations (Gelibolu, Umurbey and Dardanos) in Dardanelles Strait, Turkey.

Results and discussion. Temperature pattern was similar at the stations while salinity and organic matter values at Dardanos was different than others stations. Protein was maximum (52.48\%) in March at Gelibolu; in May (52.81\%) at Umurbey and (56.93\%) at Dardanos; lipid was maximum $(1.70 \%)$ in February at Gelibolu; in March $(1.77 \%)$ at Umurbey and in September (1.42\%) at Dardanos; ash was maximum (43.51\%) in November at Gelibolu; in September $(44.22 \%)$ at Umurbey and in December (44.98\%) at Dardanos. Carbohydrate reserves were reduced due to being used as energy for lipid synthesis in September and also carbohydrate and lipid reserves could be used as an energy source during periods of lower available nutrition for basic metabolic function. Protein, lipid, carbohydrate, ash and moisture values varied depending on food supply and reproduction period and might have been indirectly affected by environmental conditions.

Conclusions. The study clearly showed that protein, lipid, carbohydrate and ash values varied depending on food supply and reproduction period and might have been indirectly affected by environmental conditions. 


\section{- Food Technology -}

\section{Introduction}

The world's population is growing rapidly that means more people, more water and more food will be needed. Therefore, it is the obligation to know about edible species and their biochemical composition. Aegean Sea, Mediterranean Sea and Marmara Sea are home formany commercial sea cucumber species; Holothuria tubulosa, H. sanctori, H. polii, H. mammata, Stichopus regalis and S. japonicus species distributed along Turkish waters, are all exported as frozen, dried and salted, mainly Asian countries [1]. The overall trend in the export of sea cucumber is a continuous increase; total exportation amount carried out in 2014-2015 years was $154.203 \mathrm{~kg}$, and it contributed 3.225.393 $€$ to economy of the country $[2,3]$. The demonstrated economic value of sea cucumber enterprises in Turkey reflects the potential value to coastal areas. However, harvests of natural stocks by commercial fisherman could lead to rapid over-exploitation of sea cucumber. The species could potentially be developed into a new viable crop for future aquaculture [4]. In the light of these information, the current trade opportunity in sea cucumber highlight need for developing aquaculture facility. Before starting an aquaculture production of any species, one of the primary factors that what is the relationship between biochemical content and environmental factors. Sea cucumber is susceptible to changes of several environmental factors, e.g., UV exposure and elevated temperature. Under the extreme stress, it will vomit intestine and easily be subjected to autolysis, consequently causing heavy economic losses [5]. Holothurians, from a nutritional point of view, is a healthy diet with high nutritional value, as it contains high protein and low lipid rate. The major edible part of sea cucumber is body wall, in which protein is the main nutrient component [5]. Proteins, lipids and minerals which are related to the physiological and nutritional value $[6,7,8]$. Proteins play an important role in most biological processes and lipids serve as energy reserves [9].

Increase of the commercial value of sea cucumber necessitated more detailed investigation and emphasized the need to develop aquaculture studies. Biochemical composition as one of the most important of all subjects varies in accordance with geographical region of the species [10]. Only a few studies on sea cucumber in Turkey [11, $12,13,14]$. The significance of the present study is that it comprises monthly data on biochemical content of $H$. tubulosa and its relationship with environmental factor at three stations in Marmara Sea, Turkey.

\section{Material and methods}

The study was carried out between April 2013 - March 2014 at the three stations in Dardanelles Strait. The sampling stations were Gelibolu, $40.367778^{\circ} \mathrm{N}, 26.6325^{\circ} \mathrm{E}$ is close to the Marmara Sea (S1); Umurbey, $40.2525^{\circ} \mathrm{N}, 26.548056^{\circ} \mathrm{E}$ is in the central region of the Dardanelles Straits (S2); Dardanos $40.073333^{\circ} \mathrm{N}, 26.352778^{\circ} \mathrm{E}$ is near the Aegean Sea (S3), respectively. Sea cucumbers were monthly taken as 15-20 samples (total 240 specimens) from depths of $0-5 \mathrm{~m}$ by divers. Sampling could not be performed in December 2013 since no individual was present at the Station 1 and 2.

Temperature and salinity of the sea water were measured from water surface with WTW Multi 3420 Model hand-held portative multiparameter device. The sediments sampled from the all stations and burned for determination of organic matter in sediment (OM) according to Buchanan [15]. Sea cucumber samples taken from the sea were placed in ice boxes and transferred to laboratory for analyses. After the removal of coelom fluid of the samples, intestinal organs and gonads were removed. Tissues were dried before 
biochemical analyses, and the dry meat samples were kept in a deep-freezer for biochemical analyses. Biochemical composition analyses were performed solely in body wall tissue as dry weight.

The biochemical composition of the tissue was expressed as percentage of protein, lipid, ash, carbohydrate and moisture on the $H$. tubulosa. Moisture amount was measured with oven drying method [2] and ash determination AOAC method [16]. Protein was determined by using Kjeldahl method [17]. A conversion factor of 6.25 was used to convert nitrogen to crude protein for all varieties of sea cucumber. Total lipids of $H$. tubulosa species were extracted according to the Folch et al., [18]. The following formula was used for determining carbohydrate content:

Carbohydrate $(\%)=100-[$ lipid $(\%)+$ protein $(\%)+$ ash $(\%)]$.

At the end of the study, all percentage of the data was transformed by arc-sin transformation [19] prior to the ANOVA and reversed afterwards. The variations were analysed using the one-way ANOVA followed by Tukey tests for mean comparison. Correlation matrix was used to determine the relationships between the environmental factors and biochemical parameters at the significance levels. Statistical analyses were carried out using Microsoft Excel and the software program MINITAB 13A (Minitab Inc., State College, PA, USA).

\section{Results and discussion}

Figure 1 displays monthly temperature, salinity and $\mathrm{OM}$ at three stations while the maximum, minimum and mean temperature, salinity and OM were shown Table 1.

Table 1

Maximum, minimum and mean temperature, salinity and OM values at S1, S2 and S3

\begin{tabular}{|c|c|c|c|c|}
\hline & & Temperature, ${ }^{\circ} \mathrm{C}$ & Salinity, \%o & OM, \% \\
\hline \multirow{3}{*}{$\bar{n}$} & Min. & $\begin{array}{c}8.70 \\
\text { (January) }\end{array}$ & $\begin{array}{c}22.4 \\
\text { (June and July) }\end{array}$ & $\begin{array}{c}1.84 \\
(\text { March) }\end{array}$ \\
\hline & Max. & $\begin{array}{c}25.10 \\
\text { (June) } \\
\end{array}$ & $\begin{array}{c}26.40 \\
\text { (February) }\end{array}$ & $\begin{array}{c}8.81 \\
\text { (April) } \\
\end{array}$ \\
\hline & Mean & $17.63 \pm 1.85$ & $24.10 \pm 0.43$ & $3.62 \pm 0.74$ \\
\hline \multirow{3}{*}{$\tilde{N}$} & Min. & $\begin{array}{c}9.40 \\
\text { (January) }\end{array}$ & $\begin{array}{c}22.7 \\
\text { (June and July) }\end{array}$ & $\begin{array}{c}2.16 \\
\text { (February) }\end{array}$ \\
\hline & Max. & $\begin{array}{c}25.10 \\
\text { (August) }\end{array}$ & $\begin{array}{c}27.20 \\
\text { (December) }\end{array}$ & $\begin{array}{c}6.96 \\
\text { (June) }\end{array}$ \\
\hline & Mean & $17.73 \pm 1.76$ & $24.68 \pm 0.51$ & $4.31 \pm 0.51$ \\
\hline \multirow{3}{*}{$\tilde{n}$} & Min. & $\begin{array}{c}10.40 \\
\text { (January) }\end{array}$ & $\begin{array}{c}26.10 \\
\text { (September) }\end{array}$ & $\begin{array}{c}2.88 \\
\text { (May) } \\
\end{array}$ \\
\hline & Max. & $\begin{array}{c}24.00 \\
\text { (September) }\end{array}$ & $\begin{array}{c}32.30 \\
\text { (November) }\end{array}$ & $\begin{array}{c}9.79 \\
\text { (August) }\end{array}$ \\
\hline & Mean & $17.92 \pm 1.38$ & $30.33 \pm 0.49$ & $6.24 \pm 0.67$ \\
\hline
\end{tabular}



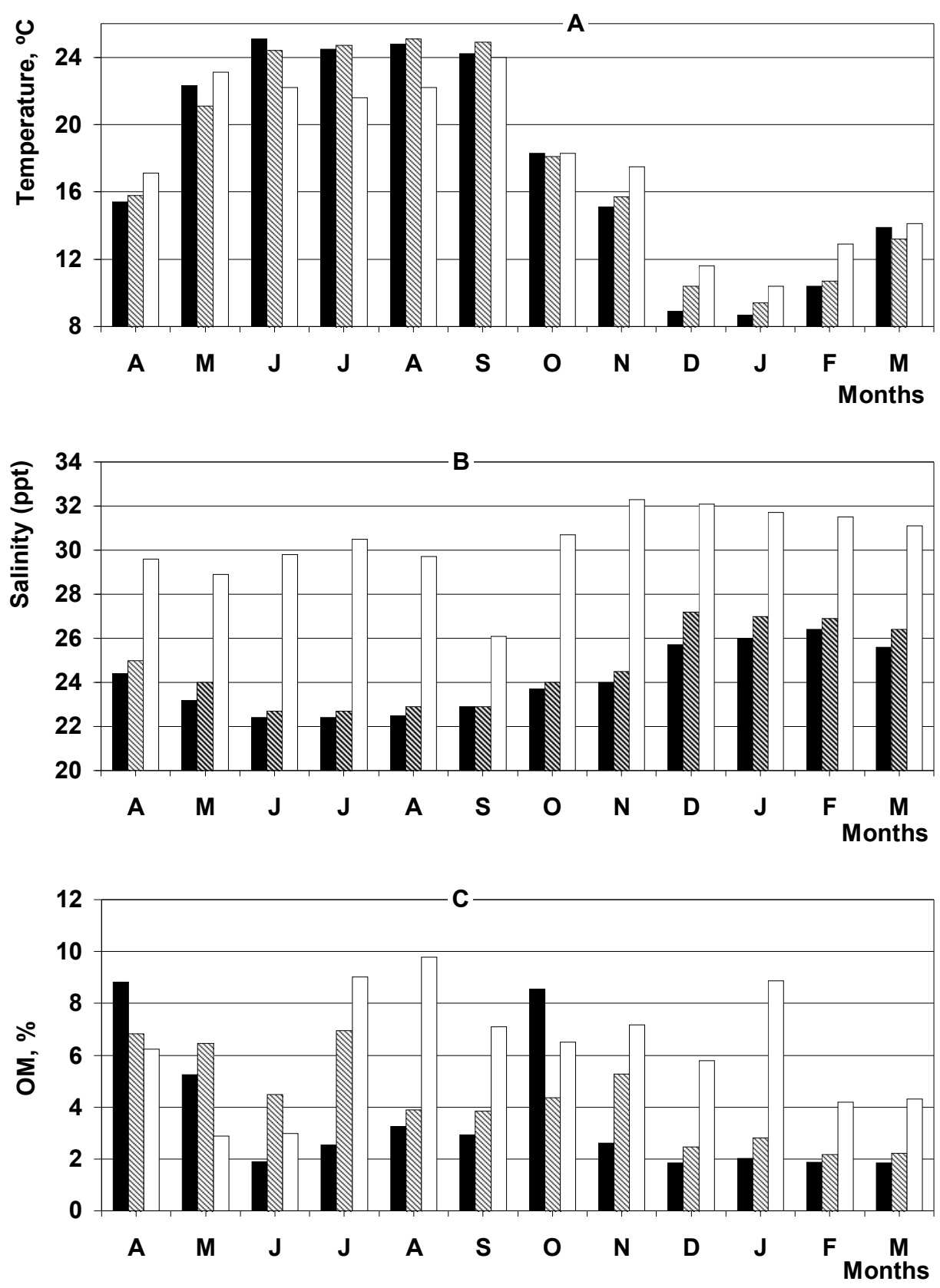

Figure 1. Monthly distribution of mean temperature (A), salinity (B), organic matter in sediment (OM) (C):

$\square \mathrm{S} 1 \mathbb{8} \mathrm{S} 2 \square \mathrm{S} 3$ 
Monthly percentages of protein, lipid, carbohydrate, moisture and ash content for all stations are presented in Figure 2 while the maximum, minimum and mean values are shown Table 2 at three stations.

Table 2

Maximum, minimum and mean protein, lipid, carbohydrate, moisture and ash values at $\mathrm{S1}, \mathrm{S2}$ and $\mathrm{S3}$

\begin{tabular}{|c|c|c|c|c|c|c|}
\hline & & Protein (\%) & Lipid (\%) & Carbohydrate (\%) & Moisture (\%) & Ash (\%) \\
\hline \multirow{3}{*}{$\bar{n}$} & Min. & $\begin{array}{l}30.38 \pm 1.41 \\
\text { (November) }\end{array}$ & $\begin{array}{c}0.57 \pm 0.13 \\
\text { (May) }\end{array}$ & $\begin{array}{c}8.37 \\
\text { (July) } \\
\end{array}$ & $\begin{array}{c}82.24 \pm 3.92 \\
\text { (March) }\end{array}$ & $\begin{array}{c}36.40 \pm 1.02 \\
\text { (February) }\end{array}$ \\
\hline & Max. & $\begin{array}{l}52.48 \pm 1.60 \\
\text { (February) }\end{array}$ & $\begin{array}{l}1.70 \pm 0.45 \\
\text { (February) }\end{array}$ & $\begin{array}{c}27.19 \\
\text { (August) }\end{array}$ & & $\begin{array}{l}43.51 \pm 0.42 \\
\text { (November }\end{array}$ \\
\hline & Mean & & $1.07 \pm 0.10$ & & & \\
\hline \multirow{3}{*}{ थै } & Min. & $\begin{array}{l}30.26 \pm 0.23 \\
\text { (November) }\end{array}$ & $\begin{array}{l}0.50 \pm 0.04 \\
\text { (July) }\end{array}$ & $\begin{array}{c}6.79 \\
\text { (May) }\end{array}$ & $\begin{array}{c}84.04 \pm 0.58 \\
\text { (January) }\end{array}$ & \\
\hline & Max. & $\begin{array}{l}52.81 \pm 0.80 \\
\text { (May) }\end{array}$ & $\begin{array}{c}1.77 \pm 0.42 \\
\text { (March) }\end{array}$ & $\begin{array}{c}28.48 \\
\text { (November) }\end{array}$ & & \\
\hline & Mean & $44.86 \pm 2.38$ & $0.97 \pm 0$ & $5.42 \pm 2.17$ & 0.17 & 38.7 \\
\hline \multirow{3}{*}{$\tilde{n}$} & Min. & & $\begin{array}{c}0.76 \pm 0.08 \\
\text { (April) }\end{array}$ & $\begin{array}{c}4.2 \\
\text { (May) }\end{array}$ & $\begin{array}{c}83.98 \pm 0.08 \\
\text { (January) }\end{array}$ & $\begin{array}{c}32.06 \pm 0.96 \\
\text { (October) }\end{array}$ \\
\hline & Max. & $\begin{array}{c}56.93 \pm 2.89 \\
\text { (May) }\end{array}$ & $\begin{array}{c}1.42 \pm 0.12 \\
\text { (September) }\end{array}$ & $\begin{array}{c}31.65 \\
\text { (October) }\end{array}$ & $\begin{array}{c}88.09 \pm 0.29 \\
\text { (August) }\end{array}$ & $\begin{array}{l}44.98 \pm 0.73 \\
\text { (December) }\end{array}$ \\
\hline & Mean & $45.60 \pm 2.28$ & $1.02 \pm 0.07$ & $15.19 \pm 2.33$ & $86.09 \pm 0.37$ & $38.19 \pm 1.22$ \\
\hline
\end{tabular}

The correlation analyses were made for all station. The results showed that salinity was negatively correlated with ash $(\mathrm{r}=-0.612, \mathrm{p} \leq 0.05)$ for $\mathrm{S} 1$. In addition, salinity was negatively correlated ash $(\mathrm{r}=-0.727, \mathrm{p} \leq 0.01)$ and $\mathrm{OM}(\mathrm{r}=-0.621, \mathrm{p}<0.05)$ and also temperature was positively correlated with ash $(\mathrm{r}=0.690, \mathrm{p} \leq 0.01)$ for $\mathrm{S} 2$. Temperature was negatively correlated with moisture $(\mathrm{r}=-0.654, \mathrm{p}<0.021)$ for $\mathrm{S} 3$. It was found that seasonal pattern in environmental factors and biochemical parameters. All parameters at three stations showed insignificant difference ( $p>0.05)$ except $\mathrm{OM}$ and salinity in Dardanos was significantly difference $(\mathrm{p}<0.01)$.

Environmental variables affect the feeding biology and reproduction and therefore biochemical variation of marine organisms. Several researchers determined the biochemical values of sea cucumber in different seas of Turkey and of the world (Table 3). 

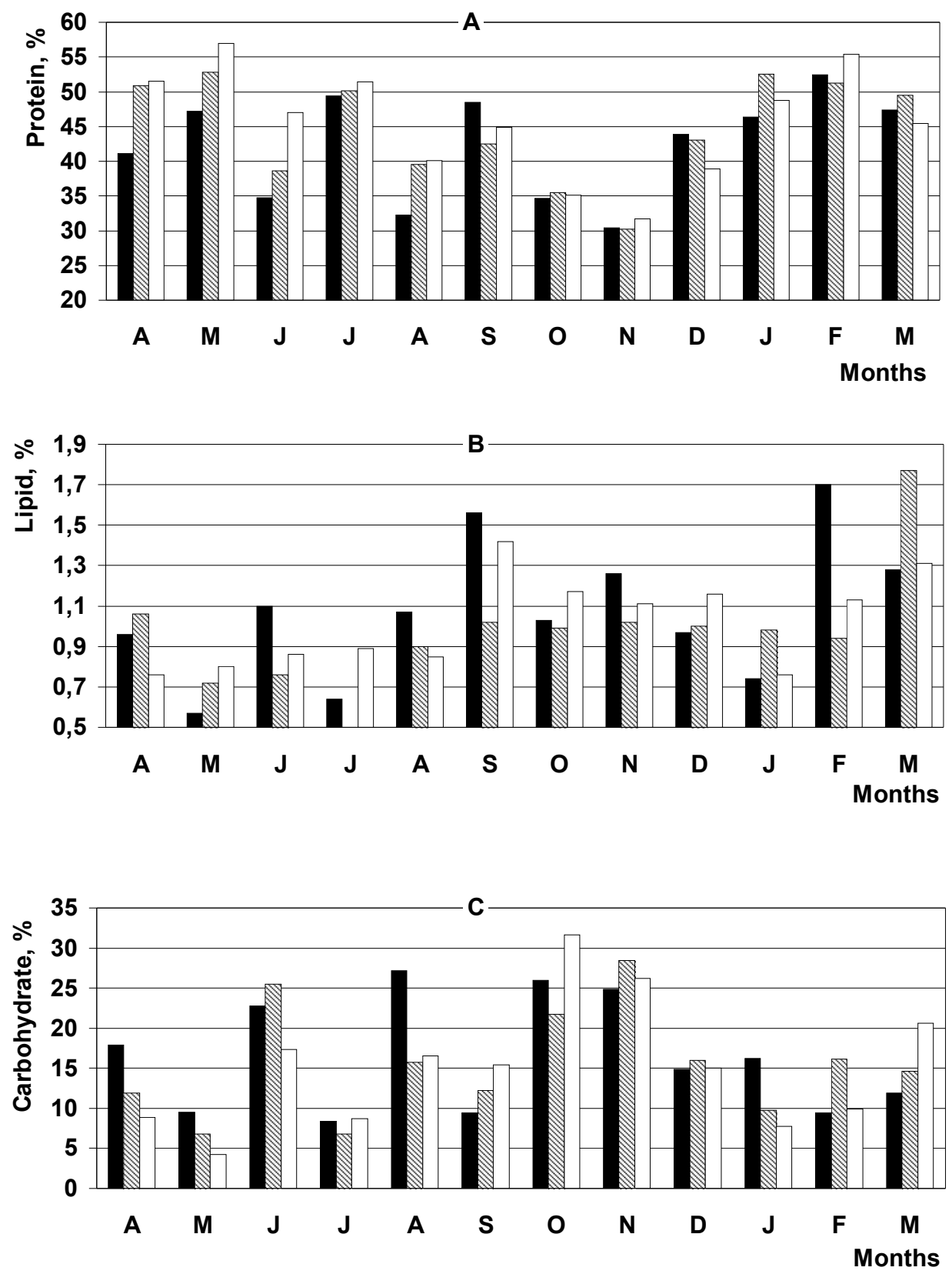

Figure 2. Monthly variation in mean moisture and protein (A), lipid (B), carbohydrate (C), moisture (D) and ash (E):

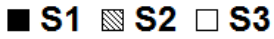



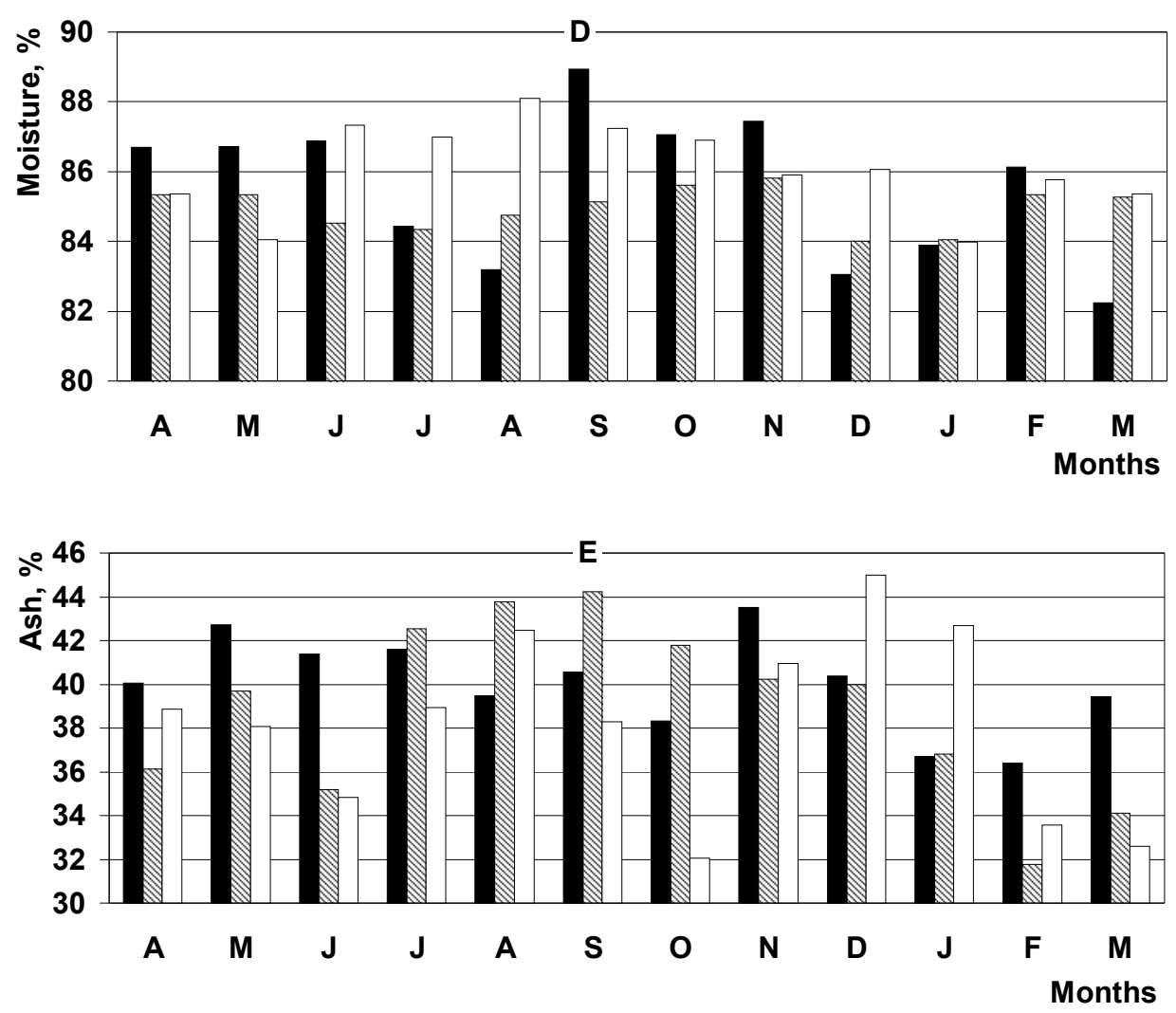

Figure 2 (the continue). Monthly variation in mean moisture and protein (A), lipid (B), carbohydrate (C), moisture (D) and ash (E) :

$\square \mathrm{S} 1 \mathbb{\mathbb { S } 2} \square \mathrm{S} 3$

Table 3

Biochemical composition of sea cucumbers sampled in Turkish waters and in other regions

\begin{tabular}{|l|c|c|c|c|}
\hline \multicolumn{1}{|c|}{ Species } & Moisture & Protein & Lipid & Ash \\
\hline H. tubulosa $[12]$ & $86.74 \pm 0.74$ & $8.18 \pm 0.04$ & $0.16 \pm 0.07$ & -- \\
\hline H. tubulosa $[11]$ & $84.30 \pm 0.2$ & $8.82 \pm 0.3$ & $0.18 \pm 0.05$ & $5.13 \pm 0.6$ \\
\hline H. tubulosa $[4]$ & -- & $44.58 \pm 1.01$ & $0.71 \pm 0.12$ & $46.43 \pm 0.51$ \\
\hline H. polii $[29]$ & -- & $36.99 \pm 0.62$ & $0.55 \pm 0.12$ & $48.22 \pm 1.09$ \\
\hline H. parva $[10]$ & $67.92 \pm 3.81$ & $17.61 \pm 0.95$ & $2.43 \pm 0.53$ & $32.74 \pm 1.17$ \\
\hline H. arenicola $[10]$ & $69.49 \pm 3.09$ & $24.37 \pm 1.93$ & $2.88 \pm 0.47$ & $10.86 \pm 0.40$ \\
\hline H. sacbra $[28]$ & 87.03 & 9.94 & 0.54 & 1.86 \\
\hline C. frondosa $[36]$ & $87.4 \pm 0.30$ & $8.34 \pm 0.50$ & $0.50 \pm 0.06$ & $2.97 \pm 0.09$ \\
\hline H. fuscogilva $[35]$ & $11.6 \pm 0.28$ & $57.8 \pm 0.41$ & $0.3 \pm 0.01$ & $26.4 \pm 0.31$ \\
\hline H. fuscopunctata $[35]$ & $7.0 \pm 0.14$ & $50.1 \pm 0.38$ & $0.3 \pm 0.01$ & $39.6 \pm 0.24$ \\
\hline P. californicus $[26]$ & $4.03 \pm 0.19$ & $47.03 \pm 0.53$ & $8.19 \pm 0.27$ & $25.73 \pm 0.25$ \\
\hline
\end{tabular}


In the present study, temperature pattern was similar between stations, salinity and OM values at Dardanos was different than other stations. The higher salinity values at S3 station were caused by the Mediterranean-derived salty water that enters the strait from Aegean Sea as an undercurrent and the influence of surface seawater of Marmara Sea [20, 21]. In addition, the highest mean OM value was observed at Dardanos $(\mathrm{p}<0.05)$ which was affected by accumulation of organic substance depending on excessive different pollution sources (such as industry and agriculture), human being activity, and heavy ship traffic [22, 23]. In the present study, biochemical pattern was not significantly different among stations $(\mathrm{p} \geq 0.05)$ and generally affected by temperature, feeding rate and reproduction. Ash negatively correlated to salinity at S1 and S2. The reason of this result might be explained that salinity fluctuation was interrelated with seasonal temperature that temperature affects many biological functions of individuals (survival, feeding rate, hibernation, aestivation, gonadal development, ext.) and biological cycle of the sea (phytoplankton availability, organic matter in sediment, detritus ext.) [23, 24, 25]. Our study demonstrated the relationship among biochemical pattern and feeding rate of $H$. tubulosa and environmental factors. The chemical composition varied seasonally and was influenced by gonadal development. Many authors reported same results that nutritional value of sea cucumber can vary depending on the feeding behavior and seasonal variations [8, 11]. The present experiment described parallel results with various workers that ash value was high due to calcareous spicule structure embedded in muscle tissue of the living. Skeletal spicules used in species determination of $H$. tubulosa are present as distributed in muscle tissue of the living [26, 27, 28, 29]. In addition, ash content of organism is influenced by feeding and depends to the food components, strongly on the origin of the inorganic matter $[30,31]$. The feeding rate might be reduced when temperature decreases below $12{ }^{\circ} \mathrm{C}$ in all station and have caused the drop of metabolic rate. The drop of metabolic rate can be attributed to a drop of the feeding at hibernation time in $H$. tubulosa which might be entered the prophase of hibernation. Many authors declared similar results for holothurians that metabolic rate is directly affected by feeding during hibernation [13, 32, 33]. However, the data showed that ash pattern of $H$. tubulosa at S3 was different from S1 and S2 because of high organic matter content. This may be reason that the predominant bottom structure consists of fine sand and mud that particle size fractions smaller than $63 \mu \mathrm{m}$ (silt-clay) at S3 [20] (data is from same project but at different viewpoints).

Dereli et al. [34] found that gonadal development of $H$. tubulosa started in May, picked in July and spawn occurred in August in Dardanelles Strait. Carbohydrate started to increase with temperature increment that could be explained by starting feeding activity in March and continued to rise independently of gonad formation until September. This result displayed that glycogen reserves were not used during gametogenic processes. Carbohydrate was negatively correlated with protein in all stations $(\mathrm{p}<0.01)$. Celik et al. [9] found parallel results. Protein reserves started to decrease from May and varied until November when minimum value was obtained. This fluctuation might occur by variation of food availability and reproduction activity. In general, lipid value was minimum in July when was signed spawning time for $H$. tubulosa by Dereli et al. [34]. Carbohydrate reserves were reduced due to being used as energy for lipid synthesis in September. Carbohydrate and lipid value were generally low (inversely protein content in winter months) [9].

It could be reason that carbohydrate and lipid reserves could be used as an energy source during periods of lower available nutrition for basic metabolic function. This study generally demonstrated that protein, lipid, carbohydrate, ash and moisture values varied depending on food supply and reproduction period and might have been indirectly affected by environmental conditions. 


\section{Conclusion}

The biochemical content of $H$. tubulosa was mainly affected by food and gonadal development. Protein is the major energy source used for gonad formation while their carbohydrate energy reserves could be affected by this metabolic energy requirement at all stations. These results indicate that protein and carbohydrate reserves were not used for the same purpose.

\section{Acknowledgements}

This study is part of the project, numbered 113Y003, supported by the Scientific and Technological Research Council of Turkey (TUBITAK). The authors thank for providing financial support.

\section{References}

1. Gonzáles-Wanguemert M., Aydin M., Conand C. (2014), Assessment of sea cucumber populations from the Aegean Sea (Turkey): First insights to sustainable management of new fisheries, Ocean Coast. Manage., 92, pp. 87-94.

2. TUIK (2017), Fishery Statistics, Turkish Statistical Institute, Ankara.

3. Lovatelli A., Conand C., Purcell S., Uthicke S., Hamel J-F., Mercier A. (2004), Advances in sea cucumber aquaculture and management, FAO Fisheries Technical Paper, 463, FAO, Rome, p. 425.

4. Sicuro B., Levine J. (2011), Sea Cucumber in the Mediterranean: A Potential Species for Aquaculture in the Mediterranean, Rev Fish Scie., 19(3), pp. 299-304.

5. Wu H.T., Li D.M., Zhu B.W., Sun J.J., Zheng J., Wang F.L., Konno K., Iang, X. (2013), Proteolysis of noncollagenous proteins in sea cucumber, Stichopus japonicus, body wall: Characterisation and the effects of cysteine protease inhibitors, Food Chem., 2(41), pp. 1287-1294.

6. Barbarino E., Lourenço S.O. (2009), Comparison of CHN Analysis and Hach Acid Digestion to Quantify Total Nitrogen in Marine Organisms, Limnol Oceanogr Methods, 7, pp. 751-760.

7. Diniz G.S., Barbarino E., Lourenco S.O. (2012), On the Chemical Profile of Marine Organisms from Coastal Sub- tropical Environments: Gross Composition and Nitrogento-Protein Conversion Factors, Oceanogr., pp. 297-320.

8. Vergara W., Rodríguez A. (2016), Nutritional Composition of Sea Cucumber Isostichopus sp. Natural Resources, 7, pp. 130-137.

9. Celik M.Y., Karayucel S., Karayucel I., Ozturk R., Eyuboglu B. (2012), Meat yield, condition index and biochemical composition of mussels (Mytilus galloprovincialis Lamarck, 1819) in Sinop, south of the Black Sea, J Aquat Food Product Tech., 21, pp. 198-205.

10. Salarzadeh A.R., Afkhami M., Bastami K.D., Ehsanpour M., Khazaali A., Mokhleci A. (2012), Proximate Composition of Two Sea Cucumber Species Holothuria pavra and Holothuria arenicola in Persian Gulf, Scholars Research Library, 3(3), pp. 1305-1311. 
11. Aydın M., Sevgili H., Tufan B., Emre Y., Kose S. (2011), Proximate Composition and Fatty Acid Profile of Three Different Fresh and Dried Commercial Sea Cucumbers in Turkey, Int J Food Sci Tech, 46, pp. 500-508.

12. Caklı S., Cadun A., Kisla D., Dincer T. (2004), Determination of Quality Characteristics of Holothuria tubulosa, (Gmelin, 1788) in Turkish Sea (Aegean Region) Depending on Sun Drying Process Step Used in Turkey, J Aquat Food Prod Tech., 13(3), pp. 69-78

13. Guney D., Emiroglu D, Tolon T., Ozden O., Sayg1 H. (2015), Growth and Survival Rate of Juvenile Sea Cucumbers (Holothuria tubulosa, Gmelin, 1788) at Various Temperatures, Turk. J. Fish. Aquat Sci, 15, pp. 533-541.

14. Ozer N.P., Mol, S., Varlık C. (2004), Effect of the Handling Procedures on the Chemical Composition of Sea Cucumber, Turk J Fish Aquat Scie., 4, pp.71-74.

15. Buchanan J.B. (1984), Sediment analysis, In Methods for the Study of Marine Benthos, N.A. Holme and A.D. McIntyre, (Blackwell Sci Publ.), 41-65.

16. AOAC (1990), Official Methods of Analysis. In Association of Official Analytical Chemists. 15th ed.; Heldrich, K. Ed, (Arlington Virginia. U.S.A.), pp. 1298

17. AOAC (2003), Official Methods of Analysis. In Association of Official Analytical Chemists. 17th ed. Gaithersburg, Maryland, USA, AOAC International. Also valid are: a second revision of this edition, 2003; the 16th edition, 1995 and the 15th edition, 1990. This last was published in Arlington, Virginia, USA, by AOAC International.

18. Folch J., Lees M. (1957), Sloanne-Stanley, GH., A Simple Method for the Isolation and Purification of Total Lipid from Animal Tissue, The Journal of Biological Chemistry., 226(1), pp. 497-509.

19. Zar J.H. (1984), Biostatistical Analysis. (Prentice Hall Upper Saddle River, N.J.).

20. Turk Culha S., Dereli H., Karaduman FR. Culha M. (2016), Assessment of trace metal contamination in the sea cucumber (Holothuria tubulosa) and sediments from the Dardanelles Strait (Turkey), Environ Sci Pollut Res., 23(12), pp. 11584-11597.

21. Turkoglu M., Yenici E., İşmen A. Kaya S. (2004), Variations of nutrient and chlorophyll-a in the Çanakkale Strait (Dardanelles), E.U. J Fish Aquat Sci., 21(1-2), pp. 93-98.

22. Aydin A., Sunlu U. (2004), The investigation of carbon and burnable substances levels which are found in the southern Aegean Sea sediments, EU J Fish Aquat Sci., 1(3-4), pp. 229-234.

23. Ilus E., Keskitalo J. (2008), The Response of Phytoplankton to Increased Temperature in the Loviisa Archipielago, Gulf of Finland. Boreal Environ Res., 13(6), pp. 503-516.

24. Lewandowska AM., Hofmann M., Matthiessen B., Sommer U., Worm B. (2014), Effects of Sea Surface Warming on Marine Plankton, Ecol Letters., 17, pp. 1-11.

25. Pitkänen H. (1991), Nutrient dynamics and trophic conditions in the eastern Gulf of Finland; the regulatory role of the Neva estuary, Aqua Fennica., 21, pp. 105-115.

26. Bechtel PJ., Olivera ACM., Demir N., Smiley S. (2013), Chemical composition of the giant red sea cucumber, Parastichopus californicus, commercially harvested in Alaska. Food Sci Nutrition, 1(1), pp. 63-73.

27. Chang-Lee M.V., Price R.J. Lampila L.E. (1989), Effect of Processing on Proximate Composition and Mineral Content of Sea Cucumbers (Parastichopus spp.), J Food Sci., 54, pp. 567-572.

28. Karnila R., Astawan M., Wresdiyati T. (2012), Analisis Kandugan Nutrisi Daging Dan Tepung Teripang Pasir (Holothuria scabra J.) Segar, Jurnal Penelitian Berkala Perikanan Terubuk, 39 (2), pp. 51-60.

29. Sicuro B., Piccinno M., Gai F., Abete MC., Danieli A., Dapra F., Mioletti S. Viella S. 
(2012), Food Quality and Safety of Mediterranean Sea Cucumbers Holothurio tubulosa and Holothuria polii in Southern Adriatic Sea, Asian J. Anim.Vet. Adv., 7(9), pp. 851859.

30. Budianto A.K. (2009), Basic of Nutrition Science, UMM Press, Malang.

31. Sudarmadji S., Haryono B., Suhadi (2007), Food and Agriculture Products Analysis, Yogyakarta.

32. Bao J., Dong S., Tian X., Wang F., Gao Q., Dong, Y. (2010), Metabolic Rates and Biochemical Compositions of Apostichopus japonicus tissue during Periods of inactivitiy, Chin J Oceanogr Limnol, 28, pp. 218-223.

33. Yang H.S., Yuan X.T., Zhou Y., Mao Y.Z., Zhang T., Liu Y. (2005), Effects of body size and water temperature on food consumption and growth in the sea cucumber Apostichopus japonicus (Selenka) with special reference to aestivation, Aquac Res., 36, pp. 1085-1092.

34. Dereli H., Turk Culha S., Culha M., Ozalp BH., Tekinay AA. (2016), Reproduction and population structure of the sea cucumber Holothuria tubulosa in the Dardanelles Strait, Turkey, Mediter Mar Sci., 17 (1), pp. 47-55.

35. Wen J., Hu C., Fan S. (2010), Chemical composition and nutritional quality of sea cucumbers, J Sci Food Agr, 90, pp. 2469-2474.

36. Zhong Y., Khan M.A., Shahidi F. (2007), Compositional Characteristics and Antioxidant Properties of Fresh and Processed Sea Cucumber (Cucumaria frondosa), $J$ Agr. Food. 